\title{
Whitening Effect of Storage Protein 2 from Silkworm Hemolymph
}

\author{
Z-Hun Kim 1*, Jung Wook Hwang1*, Joon Ho Lee1, Hojin Kim¹, Dae-Seog Lim¹, Sangjin Kang1, \\ Heui Sam Lee ${ }^{2}$, Yong-Soo Choi ${ }^{1 \#}$ \\ ${ }^{1}$ Department of Applied Bioscience, CHA University, Seongnam, Korea \\ ${ }^{2}$ Sericultural \& Apicultural Materials Division, National Academy of Agricultural Science, RDA, Suwon, Korea \\ Email: "yschoi@cha.ac.kr
}

Received 9 June 2014; revised 15 July 2014; accepted 7 August 2014

Copyright @ 2014 by authors and Scientific Research Publishing Inc.

This work is licensed under the Creative Commons Attribution International License (CC BY). http://creativecommons.org/licenses/by/4.0/

c) (i) Open Access

\section{Abstract}

This study investigated the effects of silkworm hemolymph-derived storage protein 2 (SP2) on the whitening process in mouse B16F1 melanoma cells. After the cells were treated with various concentrations of SP2 $(0.1-1.0 \mathrm{mg} / \mathrm{mL})$, cytotoxicity, melanin contents, and differences in mRNA and protein expression associated with melanogenesis were observed. No cytotoxicity was observed when cells were treated with SP2, even with increased SP2 concentrations of up to $2.0 \mathrm{mg} / \mathrm{mL}$. When treated with various SP2 concentrations in the cells, the protein and mRNA expression of tyrosinase were dose-dependently decreased, respectively, and inhibition of tyrosinase was further increased by $50.0 \%$ with increasing SP2 concentration of $1.0 \mathrm{mg} / \mathrm{mL}$. Expression mRNAs coding tyrosinase related protein-1 and protein-2 (TRP-1 and TRP-2) was also significantly decreased in a dose dependent manner. When measuring the melanin content in melanoma cells, SP2 at $1 \mathrm{mg} / \mathrm{mL}$ inhibited melanin synthesis by $73.5 \%$ compared with non-treated cells. The inhibitory effect was 2.8 -fold higher than that obtained using arbutin as a positive control. This study demonstrates that SP2, as a whitening material, is capable of suppressing melanin synthesis through the downregulation of proteins and genes in the melanin biosynthesis pathway.

\section{Keywords}

Silkworm Hemolymph, Storage Protein 2, Melanin, Tyrosinase, Melanoma Cells

\section{Introduction}

Recently, the cosmetic industry has been rapidly expanding its market size with great potential due to an in-

\footnotetext{
*The first two authors contributed equally to this study.

"Corresponding author.
}

How to cite this paper: Kim, Z-H., Hwang, J.W., Lee, J.H., Kim, H., Lim, D.-S., Kang, S., Lee, H.S. and Choi, Y.-S. (2014) Whitening Effect of Storage Protein 2 from Silkworm Hemolymph. Advances in Bioscience and Biotechnology, 5, 758-767. 
creasing interest in beauty. Subsequently, various bioactive materials for cosmetic ingredients have been chemically synthesized to meet growing economic and consumer demands [1]. However, it is often reported that synthetic materials can be potentially harmful and result in inflammations to human skin [2]-[4]. Thus, alternative materials have been sought and studied. Research indicates that consumers prefer cosmetics made from natural sources, such as plants, insects and others [5] [6].

Among such natural compounds, a silkworm protein derived from domesticated Bombyx mori has been used effectively in biological research, including an ingredient in cosmetics [7]-[10]. Specifically, silk proteins have well-known bioactive characteristics and functions, such as anti-oxidation, UV-resistance, biocompatibility, biodegradability, inhibitory tyrosine activity, and others [11]. Furthermore, after the effectiveness of these proteins in moisturizing and preventing inflammation was revealed by several studies, research into their cosmetic use has followed [11] [12].

There has been great interest in functional whitening cosmetics in the market because human skin is directly exposed to various environmental stresses that cause accelerated depigmentation, freckles, and skin darkness [13] [14]. Melanin, which is produced in skin melanosomes, not only plays an important role in protecting the skin against UV radiation but is also responsible for skin color [11] [12]. Thus, upon exposure of skin to UV radiation, melanogenesis is initiated through an enzyme called tyrosinase, along with tyrosinase-related proteins (TRPs) [3]. TRPs, such as TRP-1 (5,6-dihydroxyindole-2-carboxylic acid oxidase) and TRP-2 (dopachrometautomerase), are key enzymes for melanin biosynthesis [15]. After tyrosinase oxidizes tyrosine to Dopaquinone, TRP-2 catalyses the conversion of Dopachrome to DHICA (5,6-dihydroxyindole-2-carboxylic acid) [16]. Then, TRP-1 oxidizes DHICA to indole-5,-6-quinone carboxylic acid. Thus, overexpression of TRP-1 and TRP-2 causes the skin color darkens [17]. To obtain a whitening effect from cosmetics, the substance must thus be capable of effectively controlling melanin synthesis via mechanisms such as the inhibition of melanin formation. The regulation of key genes or enzymes in the pathway therefore needs to be characterized for use in cosmetic ingredients.

The functions of silk proteins have been widely studied. However, few studies have investigated the protein-derived silkworm hemolymph, which is a fluid in the silkworm circulatory system that plays a role in supplementing nutrients and determining sex hormones during metamorphosis. Storage protein-2 (SP2) and 30K protein, which are the most highly expressed proteins in silkworm hemolymph, are part of a group of structurally related proteins [18] and are approximately $72 \mathrm{kDa}$ and $30 \mathrm{kDa}$ in molecular size, respectively [19]. Some studies on these have been conducted, and they have been found to exert functions in the suppression of programmed cell death, apoptosis, and oxidative stress [20]-[23]. Although these proteins have been researched as mentioned above, the application of these proteins as whitening agents is still not available and has not yet been tested.

In our previous studies, we found that soluble silkworm gland hydrolysate exhibits skin whitening effects and anti-aging activity through the inhibition of tyrosinase and elastase activities, respectively [24]. In the present study, we isolated SP2 from silkworm hemolymph to examine its potential as a whitening agent. In an effort to characterize SP2's inhibitory effect and mechanisms, we investigated the influence of SP2 on the expression level of mRNA and enzymes involved in melanin synthesis as well as its cytotoxicity and any differences in the melanin content of B16F1 melanoma cells upon SP2 treatment.

\section{Materials and Methods}

\subsection{Isolation of SP2 from Silkworm Hemolymph}

Freeze-dried 5-instar 7 days silkworms were kindly provided by the Rural Development Administration (RDA, Suwon, Korea). Silk glands present in freeze-dried silkworms were removed using a ball mill, and the other parts of the silkworm were used for extraction of hemolymph. To extract water-soluble proteins, including SP2, $30 \mathrm{~g}$ of freeze-dried silkworm pieces were added to $1 \mathrm{~L}$ of $20 \mathrm{mM}$ Tris-HCl buffer (pH 9.0) and stirred using a magnetic stirrer for $30 \mathrm{~min}$ at room temperature. The solution was heated for $30 \mathrm{~min}$ to inactivate tyrosinase at $60^{\circ} \mathrm{C}$ then centrifuged for $30 \mathrm{~min}$ at $10,000 \mathrm{rpm}$, and the supernatant containing the soluble proteins was transferred to a $50 \mathrm{~mL}$ conical tube. Silkworm hemolymph-derived SP2 was isolated by using the AKTA FPLC system (GE Healthcare, Pittsburgh, PA, USA). The solution was then loaded on a column that was filled with Sepharose Q resin (GE Healthcare, Pittsburgh, PA, USA) pre-equilibrated with $20 \mathrm{mM}$ Tris-HCl buffer (pH 9.0). After sample loaded on the column, it was eluted with $20 \mathrm{mM}$ Tris- $\mathrm{HCl}$ (pH 9.0), and $1 \mathrm{M} \mathrm{NaCl}$ buffer at a flow 
rate of $1 \mathrm{~mL} / \mathrm{min}$. The eluent was monitored at $280 \mathrm{~nm}$ and each fraction was collected. Step-gradient method was used for the protein separation. SP2 from the eluent were identified by a gel electrophoresis as described later.

\subsection{Analysis of SP2 Molecular Weight}

The molecular weight of silkworm hemolymph-derived SP2 was identified using gel electrophoresis using a $12 \%$ sodium dodecyl sulfate-polyacrylamide gel (SDS-PAGE). The gel was then stained using Coomassie Brilliant Blue R-250 (Amresco Inc., Solon, OH, USA) for $1 \mathrm{hr}$, and a destaining process was conducted in destaining solution (MeOH: Acetic acid: Distilled water 1:1:8) overnight. The molecular weight of SP2 was then analyzed using a broad-range pre-stained marker (ebm-1032, ELPIS bio, Daejeon, Korea).

\subsection{Cell Culture}

Melanoma B16F1 cells were purchased from the Korean Cell Line Bank (KCLB, Seoul, Korea). The cells were cultured in Dulbecco's Modified Eagle's Medium (DMEM, HyClone Laboratories Inc., Logan, UT, USA) supplemented with $10 \%$ fetal bovine serum (FBS, HyClone Laboratories Inc., Logan, UT, USA) and $1 \%$ penicillin-streptomycin (HyClone Laboratories Inc., Logan, UT, USA) in a humidified atmosphere containing $5 \% \mathrm{CO}_{2}$ at $37^{\circ} \mathrm{C}$. Melanoma B16F1 cells were cultured in 6-well plates, 24-well plates, and 96-well plates depending on assay procedure. After the cells were seeded in plates, they were allowed to attach to the plate for $24 \mathrm{hr}$. Adherent cells were used in all experiments.

\subsection{Measurement of Cell Viability}

Cell viability was evaluated using the Cyto $\mathrm{X}^{\mathrm{TM}}$ cell viability assay kit (LPS solution, Daejeon, Korea). SP2 was dissolved in distilled water prior to addition to the cell media. Melanoma cells were treated with $0,0.1,0.2,0.5$, 1.0, or $2.0 \mathrm{mg} / \mathrm{mL}$ of SP2 and then incubated for $24 \mathrm{hr}$ in the mixture to observe cell proliferation. After incubation, cells were treated with $20 \mu \mathrm{L}$ WST-1 per well and again incubated at $37^{\circ} \mathrm{C}$ in a $5 \% \mathrm{CO}_{2}$ incubator for $3 \mathrm{hr}$. Sample absorbance was determined at $450 \mathrm{~nm}$ using an ELISA microplate reader (Epoch microplate spectrophotometer, BioTek Inc., Winooski, VT, USA) to assess cytotoxicity with various concentrations of SP2. The mean and standard deviation (SD) values were obtained from three independently performed experiments.

\subsection{Measurement of Melanin Content}

Melanoma B16F1 cells $\left(4 \times 10^{4}\right.$ cells/well) were seeded in 24 -well plates. Then, fresh medium containing various SP2 concentrations $(0.1-1.0 \mathrm{mg} / \mathrm{mL})$ was added to the plate and incubated at $37^{\circ} \mathrm{C}$ in a $\mathrm{CO}_{2}$ incubator for $96 \mathrm{hr}$ to observe distinct inhibition effect and color variations. Cells were harvested using a $1 \mathrm{~mL} 0.25 \%$ trypsin-EDTA solution treatment. The cells were transferred to $1.5 \mathrm{~mL}$ microtubes and centrifuged for $5 \mathrm{~min}$ at 1500 rpm for harvesting. After the collected cells were disrupted using a homogenizer (PT1200 E, Kinematica, Luzern, Switzerland), intracellular melanin was dissolved in $2 \mathrm{M} \mathrm{NaOH}$ at $100^{\circ} \mathrm{C}$ for $1 \mathrm{hr}$. To measure melanin content, $200 \mu \mathrm{L}$ of the melanin mixture were placed in a 96-well plate, and absorbance was measured at $405 \mathrm{~nm}$ using the ELISA reader. Standard curves were prepared using synthetic melanin (Sigma-Aldrich, St. Luis MO, USA). Arbutin $(0.2 \mathrm{mg} / \mathrm{mL})$ was used as a positive control. The inhibition rate of melanin synthesis was calculated using the following formula:

$$
\text { Inhibition rate of melanin syntheisis }=\left(1-\frac{O D_{\text {sample }}}{O D_{\text {control }}}\right) \times 100
$$

\subsection{Measurement of DPPH Radical-Scavenging Activity}

The antioxidant capacity of 30K protein and SP2 was determined according to a previous report [24], and ascorbic acid was used as a positive control. One-hundred sixty microliters of a $0.2 \mathrm{mM}$ methanolic solution of DPPH (2,2-diphenyl-1-picrylhydrazyl) was added to $40 \mu \mathrm{L}$ of a $0.01,0.1,1,10,100$, or $1000 \mu \mathrm{g} / \mathrm{mL}$ SP2 solution in 96-well plates. The mixtures were then incubated at $37^{\circ} \mathrm{C}$ for $30 \mathrm{~min}$. The activity of the mixture was spectrophotometrically determined at $517 \mathrm{~nm}$ using an ELISA reader. The percentage of DPPH scavenging activity was calculated using the following formula: 


$$
\text { Scavenging activity }(\%)=\left(1-\frac{O D_{\text {sample }}}{O D_{\text {control }}}\right) \times 100
$$

DPPH radical scavenging activity was expressed as $\mathrm{IC}_{50}$.

\subsection{Tyrosinase Inhibition by SP2}

The tyrosinase activity assay was performed with L-DOPA as the substrate, as previously described [24]. Melanoma B16F1 cells were seeded at $3 \times 10^{5}$ cells/well in 6 -well plates, and $\alpha$-melanocyte stimulating hormone $(\alpha-\mathrm{MSH})$ was added to the medium to a final concentration of $200 \mathrm{nM}$ to enhance melanin production. Then, the cells were treated with $0.1,0.2,0.5$, or $1.0 \mathrm{mg} / \mathrm{mL}$ of SP2 and the mixtures were added to the plate. Arbutin (0.2 $\mathrm{mg} / \mathrm{mL}$ ) was used as a positive control. The plate was incubated at $37^{\circ} \mathrm{C}$ in a $\mathrm{CO}_{2}$ incubator, and variations in absorbance at $490 \mathrm{~nm}$ over time were measured every $10 \mathrm{~min}$ for $1 \mathrm{hr}$. The percentage of inhibition of tyrosinase activity was calculated using the following formula:

$$
\text { Inhibition rate of tyrosinase activity }(\%)=\left(1-\frac{O D_{\text {sample }}}{O D_{\text {control }}}\right) \times 100
$$

\subsection{Quantitative Real-Time PCR Analysis of the Expression of Genes Related to Melanin Synthesis}

Melanoma B16F1 cells $\left(1 \times 10^{5}\right.$ cells/well) were seeded in 6-well plates. Adherent cells were treated with 0 , 0.1 , $0.2,0.5$, or $1.0 \mathrm{mg} / \mathrm{mL}$ SP2. The cells were incubated for $48 \mathrm{hr}$ and harvested for mRNA extraction. Total RNA was extracted from the B16F1 cells using the easy-spin ${ }^{\mathrm{TM}}$ total mRNA extraction kit (iNtRON Biotech., Seongnam, Korea) according to the manufacturer's instructions and was used to synthesize cDNA for analysis using the StepOnePlus Real-Time PCR system (Applied Biosystems, Grand Island, NY, USA). Equal amounts of total mRNA were used for each analysis and $\beta$-actin was used as a reference gene. Primer sequences are listed in Table 1.

\subsection{Statistical Analysis}

Data are express as the mean \pm standard deviation for each experiment. Statistical analyses were performed using the t-test for pair-wise comparisons within Sigma Plot 10.0 software (Systat Software, San Jose, CA, USA). The values of $p<0.05$ were considered statistically significant.

\section{Results}

\subsection{The Effect of SP2 on Cell Viability}

The cytotoxic effect of various SP2 concentrations on melanoma B16F1 cells was investigated. Cell viability was determined using a WST-1 assay. Figure 2 shows the effect of SP2 on cell viability and proliferation. SP2

\begin{tabular}{|c|c|c|}
\hline Genes & Primers (5’-3’) & Amplicon (bp) \\
\hline \multirow{2}{*}{ Tyrosinase } & F: 5'-GAA TGG AAC AAT GTC CCA AG-3' & 49 \\
\hline & R: 5'-CCT TCG CAG CCA TTG TTC-3' & 46 \\
\hline \multirow{2}{*}{ TRP-1 } & F: 5'-TCC TTG GAA GAG TAC GAT AC-3' & 49 \\
\hline & R: 5'-ACG CTG CAC TGC TGG TCT-3' & 47 \\
\hline \multirow{2}{*}{ TRP-2 } & F: 5’-TTG CCA CAC TCA GCA GCC-3' & 47 \\
\hline & R: 5’-TTC TCT TCA GCC ACT CAT CA-3' & 49 \\
\hline \multirow{2}{*}{$\beta$-actin } & F: 5'-ACC CTA AGG CCA ACC GTG-3' & 47 \\
\hline & R: 5’-GCC TGG ATG GCT ACG TAC-3’' & 47 \\
\hline
\end{tabular}

Table 1. Primers for real-time PCR. 
treatment did not result in any significant inhibition of cell growth or any toxicity in melanoma B16F1 cells with all of the tested SP2 concentrations (ranging from 0.1 to $2.0 \mathrm{mg} / \mathrm{mL}$ ).

\subsection{The Effect of SP2 on Melanin Content}

The inhibitory effect of SP2 on melanin biosynthesis in melanoma B16F1 cells was examined in comparison with the effect of arbutin at $0.2 \mathrm{mg} / \mathrm{mL}$ as a positive control. $\alpha$-MSH treatment at $200 \mathrm{nM}$ enhanced the melanin content in melanoma B16F1 cells by $37.5 \pm 1.5 \%$ compared with non-treated cells $(p<0.05)$, as shown in Figure 3. SP2 inhibited dose-dependently melanin formation within the cell. SP2 and arbutin at same concentration $(0.2 \mathrm{mg} / \mathrm{mL})$ resulted in inhibition rates of $31.8 \pm 6.3 \%$, and $26.5 \pm 5.2 \%$ in the presence of $\alpha-\mathrm{MSH}$, respectively $(p<0.05)$. Moreover, when SP2 was treated at $1.0 \mathrm{mg} / \mathrm{mL}$, melanin content was decreased up to $26.6 \pm 1.2 \%$ compared with only $\alpha$-MSH added group (Second column in Figure 3).

\subsection{DPPH Radical Scavenging Activity}

To evaluate the antioxidant capacity of SP2, DPPH radical scavenging activities were examined and compared to ascorbic acid as a reference. As shown in Table 2, two proteins derived from silkworm hemolymph inhibited scavenging activity, and the $\mathrm{IC}_{50}$ values of $30 \mathrm{~K}$ and SP2 were calculated to be $91.2 \pm 6.0 \mu \mathrm{g} / \mathrm{mL}$ and $35.8 \pm 4.5$ $\mu \mathrm{g} / \mathrm{mL}$, respectively. These $\mathrm{IC}_{50}$ values were much lower than those for ascorbic acid $(0.57 \pm 0.02 \mu \mathrm{g} / \mathrm{mL})$.

\subsection{The Effect of SP2 on the mRNA Expression of Tyrosinase and on Tyrosinase Activity}

The effect of SP2 on tyrosinase expression was investigated at the transcriptional and translational levels. Arbutin was chosen as the reference whitening material for this experiment. As shown in Figure 4(a), SP2 dose-dependently inhibited mRNA expression of tyrosinase in melanoma B16F1 cells. Among the tested group, arbutin demonstrated lowest gene expression level (Approx. 0.2) SP2 showed a potent inhibition of tyrosinase enzyme when compared with arbutin (Figure 4(b)). When treated SP2 and arbutin at a same concentration $(0.2 \mathrm{mg} / \mathrm{mL}$ ), SP2 showed $10 \%$ higher activity than arbutin. Specifically, SP2 treatment at $1.0 \mathrm{mg} / \mathrm{mL}$ resulted in a $50.0 \%$ decrease in tyrosinase synthesis $(p<0.05)$. SP2 activity was not better than arbutin when SP2 concentration was below $0.1 \mathrm{mg} / \mathrm{mL}$.

\subsection{The Effect of SP2 on the mRNA Expression of TRP-1 and TRP-2}

SP2 significantly inhibited mRNA expression of TRPs in melanoma B16F1 cells in a dose-dependent manner (Figure 5(a) and Figure 5(b)). Specifically, $48 \mathrm{hr}$ after SP2 treatment at $1.0 \mathrm{mg} / \mathrm{mL}$, mRNA expression of TRP-1 and TRP-2 was significantly inhibited by $32.7 \%$, and $24.6 \%$, respectively, compared with the non-treated group $(p<0.05)$. These values were similar to that of arbutin at $0.2 \mathrm{mg} / \mathrm{mL}$.

\section{Discussion}

Although there are many cosmetically active compounds derived from natural sources, each must be characterized, and their activity and stability must be evaluated before they can be utilized in cosmetics [25]. In addition, compound cytotoxicity must be evaluated to ensure skin health. In our previous studies, we exploited compounds from silkworm for various biological uses. For example, we manufactured and characterized novel methods for the production of water-soluble hydrolysate using silkworm glands [26]. Hydrolysate demonstrated superior activity in enhancing the production of albumin-erythropoietin (Alb-EPO) in transgenic Chinese hamster ovary (CHO) cells [27] and in preventing cell death and ROS scavenging in human dermal fibroblasts without resulting in cytotoxicity or growth inhibition [28]. Recently, we uncovered anti-oxidant and anti-aging activities in silkworm gland hydrolysate, which may be applicable for cosmetics [24]. Based on these studies, we aimed to extend the potential applications of silk worm hemolymph proteins in this study by examining their potential use as a bioactive compound for skin whitening.

Table 2. Comparison of DPPH radical-scavenging activity.

\begin{tabular}{cccc}
\hline & 30K protein & SP2 & Ascorbic acid \\
\hline $\mathrm{IC}_{50}$ of DPPH assay $(\mu \mathrm{g} / \mathrm{mL})$ & $91.2 \pm 6.0$ & $35.8 \pm 4.5$ & $0.57 \pm 0.02$ \\
\hline
\end{tabular}


First, we isolated an important protein referred to as "storage-protein 2" from silkworm hemolymph to characterize its whitening effect and confirmed the molecular weight of the protein using SDS-PAGE (Figure 1). SP2 was located near the $70 \mathrm{kDa}$ protein marker on a gel, as previously reported [29]. Toxicity tests of cosmetic ingredients as a typical in vitro assay must be primarily considered and evaluated, although they have the cosmetically high potentials in vitro [30]. To test the cytotoxicity of SP2, we used a WST-1 assay to measure the viability of melanoma B16F1 cells, which are well-known to employ melanogenic mechanisms similar to normal human melanocytes [31]. SP2 treatment did not result in any significant cytotoxicity to the cells (Figure 2). Furthermore, when even the SP2 dose was increased up to $2 \mathrm{mg} / \mathrm{mL}$, the toxicity could not also found inhibitory effects of melanoma B16F1 on cell viability and growth. The effect of SP2 on melanin formation in melanoma B16F1 cells was investigated, and the melanin content was significantly decreased after SP2 treatment (Figure 3). In particular, SP2-treated cells showed either a higher or similar efficiency of melanin inhibition in melanona cells depending on the presence or absence of $\alpha$-MSH, respectively. These experimental results indicate a definite potential for SP2 as a candidate whitening compound, with a satisfactory functional inhibitory effect on melanin production and without adverse effects on cell viability. It is well-known that reactive oxygen species (ROS) are generated during melanogenesis, and considered to play an important role in proliferating melanocyte [32]. ROS not only place the melanocytes under high grade oxidative stress but also cause skin aging [33] [34].

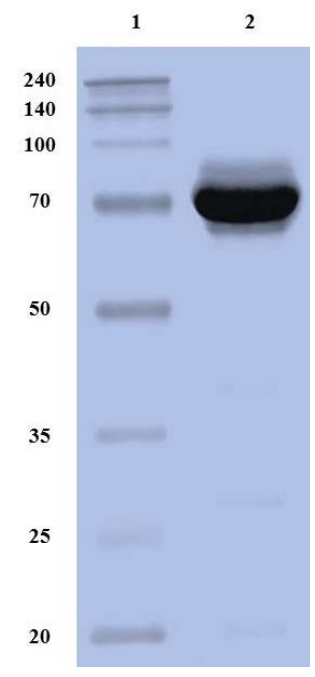

Figure 1. Molecular weight purification of SP2. Lane 1, marker; Lane 2, purified SP2.

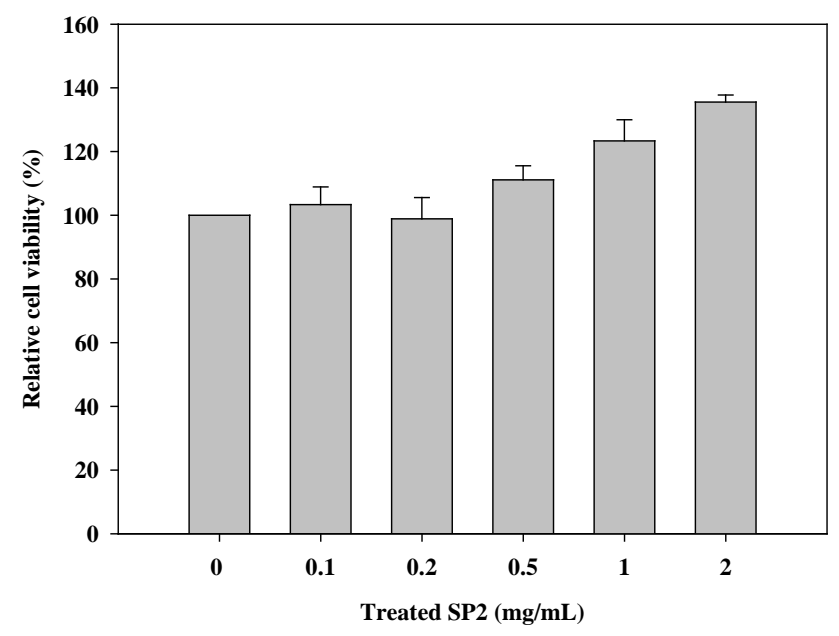

Figure 2. Cell viability of melanoma B16F1 cells by SP2 treatment. Viable cell numbers were estimated using a WST-1 assay. 


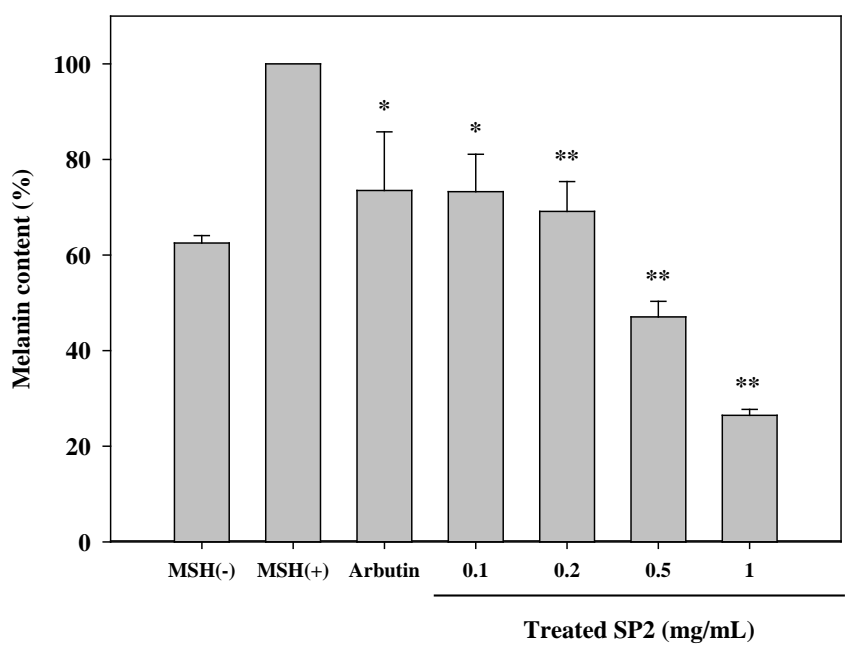

Figure 3. Inhibition of melanin formation by SP2 treatment in melanoma B16F1 cells.

In this regard, antioxidants, such as ascorbic acid, are able to interfere with the melanin formation and melanosomes transference. Thus, those have been widely employed as inhibitory agents of melanin biosynthesis [35]. The antioxidant capacity of SP2 was evaluated by measuring DPPH radical scavenging activity in comparison with ascorbic acid as well as with $30 \mathrm{~K}$, which have been relatively well-studied for apoptotic inhibiting activity [8]. SP2 showed a 2.6-fold higher free radical scavenging activity when compared with 30K (second and third columns in Table 2). The $\mathrm{IC}_{50}(33.0 \pm 3.2 \mathrm{mg} / \mathrm{mL})$ of silkworm grand hydrolysate (SGH), which is a known anti-oxidant, antiviral agent, and inhibitor of tyrosine activity [11], was similar to that of SP2 in our previous reports [24]. Although SP2 exhibited higher anti-oxidant activity than 30K, SP2 did not show superior anti-oxidant activity when compared with ascorbic acid. Thus, to clearly elucidate the depigmentation mechanism of SP2, we conducted comparative studies of protein and mRNA analyses for various important enzymes associated with the melanin synthesis pathway. As described in the introduction, there are numerous proteins involved in melanogenesis. Among these, tyrosinase, TRP-1, and TRP-2 are essential for melanin synthesis [36]. Melanin is divided into two categories according to color: dark brown (eumelanin) and brownish-red (phaeomelanin) [36]. Tyrosinase is an essential factor for the synthesis of the two types of melanin, whereas TRP-1 and TRP-2 are more deeply involved in eumelanin synthesis [36]. In other words, quantity of melanin mainly is determined by tyrosinase activity at early stage of melanogenesis, and TRPs are contributed to the color of melanin. When treating melanoma cells with SP2, there was a significant decrease in the mRNA expression of tyrosinase and an inhibition of tyrosinase activity (Figure 4). Furthermore, as shown in Figure 5, SP2 at $1 \mathrm{mg} / \mathrm{mL}$ had an inhibitory effect on mRNA expression of TRP-1 and TRP-2 was similar to or higher than that of arbutin at 0.2 $\mathrm{mg} / \mathrm{mL}$. These results suggest that SP2 effectively inhibits melanogenesis in melanoma B16F1 cells by suppressing protein and mRNA encoding tyrosinase, the mRNAs encoding TRP-1 and TRP-2. These results also suggest that SP2 inhibition of melanin biosynthesis by SP2 occurs through down regulation of mRNA and proteins involved in process of melanogenesis, rather than through ROS scavenging. Although SP2 showed inhibitory effect on TRPs synthesis at mRNA, based on the results, it could be deduced that SP2 more effectively inhibit the melanin formation within the cells by regulating tyrosinase activity. In particular, Whereas SP2 did not showed higher inhibitory effect on mRNA expression of tyrosinase than that of arbutin, suppression of tyrosinase activity and decrease of melanin content by SP2 were comparable with arbutin.

\section{Conclusion}

In conclusion, we examined possibility of SP2 isolated from silkworm hemolymph as a whitening material. In this study, it was demonstrated that SP2 decreased the melanin content and significantly inhibited TRPs encoding mRNA levels as well as tyrosinase protein and mRNA levels in B16F1 melanoma cells. Additionally, no significant melanoma cell cytotoxicity, which is an important consideration for a potential cosmetic ingredient, 


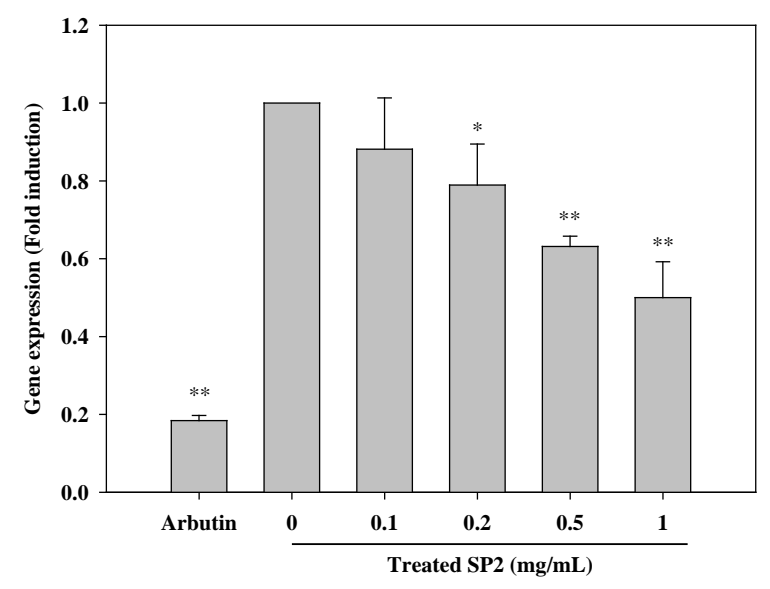

(a)

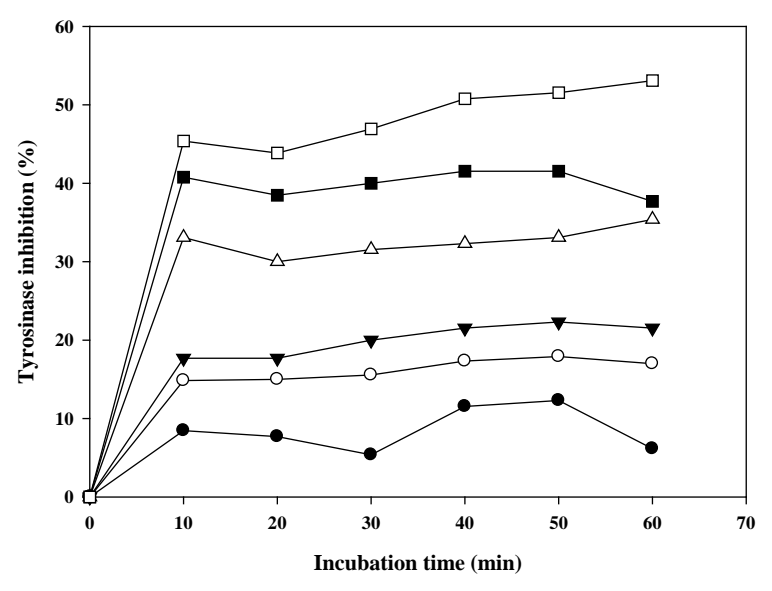

(b)

Figure 4. Expression of mRNA encoding tyrosinase and cellular tyrosinase activity a function of treated SP2 concentration in melanoma B16F1 cells. (a) Tyrosinase mRNA expression; (b) Tyrosinase inhibition as a function of time. $\nabla, 0.2$ $\mathrm{mg} / \mathrm{mL}$ Arbutin; •, $0 \mathrm{mg} / \mathrm{mL} \mathrm{SP} 2$ (non-treated);, $0.1 \mathrm{mg} / \mathrm{mL} \mathrm{SP} 2 ; \Delta, 0.2 \mathrm{mg} / \mathrm{mL} \mathrm{SP} 2 ; \mathbf{\square}, 0.5 \mathrm{mg} / \mathrm{mL} \mathrm{SP} 2 ; \square, 1.0$ $\mathrm{mg} / \mathrm{mL}$.

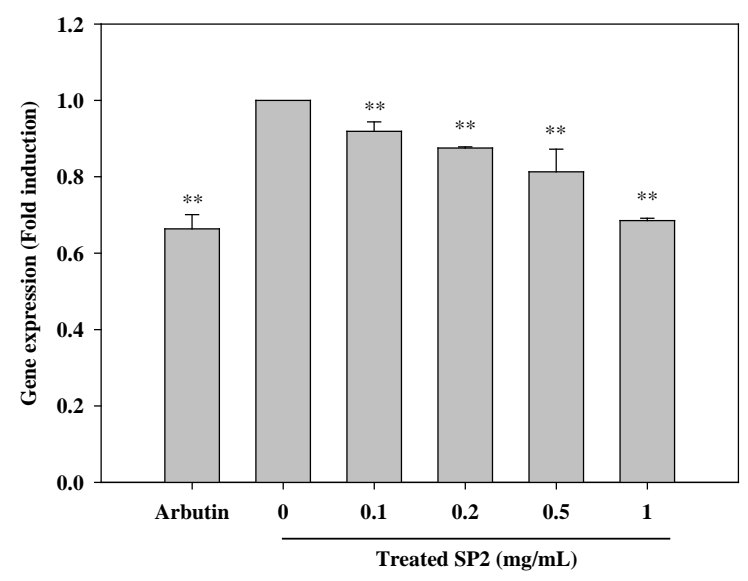

(a)

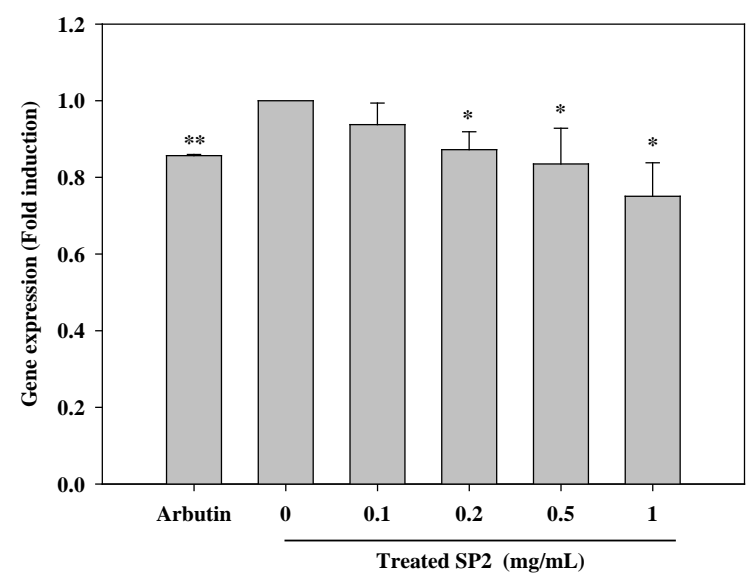

(b)

Figure 5. Expression of mRNA encoding TRPs as a function of treated SP2 concentration in melanoma B16F1 cells. (a) mRNA expression of TRP-1; (b) mRNA expression of TRP-2.

was observed. However, further studies, such as expression level of mRNA encoding TRPs, mass extraction process, and in vivo tests (skin test, safety test), should be performed. This finding provides key preliminary data supporting SP2 as a whitening reagent for the treatment of pigmentation disorders in the cosmetic industry.

\section{Acknowledgements}

This work was supported by the Rural Development Administration, Ministry of Agriculture, Food, and Rural Affairs, Korea (Project No. PJ007354), and by the Small and Medium Business Administration, Ministry of Trade, Industry, and Energy, Korea (Project No. S2083387), for which the authors are grateful.

\section{References}

[1] (2014) Global Market for Cosmetic Chemicals to Reach $\$ 21.2$ bn by 2018: Global Industry Analysts. Focus on Surfactants, 3, 5-6. http://dx.doi.org/10.1016/S1351-4210(14)70070-8

[2] Curto, E.V., Kwong, C., Hermersdörfer, H., Glatt, H., Santis, C., Virador, V., Hearing Jr., V.J. and Dooley, T.P. (1999) Inhibitors of Mammalian Melanocyte Tyrosinase: In Vitro Comparisons of Alkyl Esters of Gentisic Acid with Other Putative Inhibitors. Biochemical Pharmacology, 57, 663-672. http://dx.doi.org/10.1016/S0006-2952(98)00340-2 
[3] Peng, L.H., Liu, S., Xu, S.Y., Chen, L., Shan, Y.H., Wei, W., Liang, W.Q. and Gao, J.Q. (2013) Inhibitory Effects of Salidroside and Paeonol on Tyrosinase Activity and Melanin Synthesis in Mouse B16F10 Melanoma Cells and Ultraviolet B-Induced Pigmentation in Guinea Pig Skin. Phytomedicine, 20, 1082-1087. http://dx.doi.org/10.1016/j.phymed.2013.04.015

[4] Burnett, C.L., Bergfeld, W.F., Belsito, D.V., Hill, R.A., Klaassen, C.D., Liebler, D.C., Marks, J.G., Shank, R.C., Slaga, T.J. and Snyder, P.W. (2010) Final Report of the Safety Assessment of Kojic Acid as Used in Cosmetics. International Journal of Toxicology, 29, 244S-273S. http://dx.doi.org/10.1177/1091581810374651

[5] Vermaak, I., Kamatou, G.P.P., Komane-Mofokeng, B., Viljoen, A.M. and Beckett, K. (2011) African Seed Oils of Commercial Importance-Cosmetic Applications. South African Journal of Botany, 77, 920-933. http://dx.doi.org/10.1016/j.sajb.2011.07.003

[6] Uchida, R., Ishikawa, S. and Tomoda, H. (2014) Inhibition of Tyrosinase Activity and Melanine Pigmentation by 2Hydroxytyrosol. Acta Pharmaceutica Sinica B, 4, 141-145. http://dx.doi.org/10.1016/j.apsb.2013.12.008

[7] Manosroi, A., Boonpisuttinant, K., Winitchai, S., Manosroi, W. and Manosroi, J. (2010) Free Radical Scavenging and Tyrosinase Inhibition Activity of Oils and Sericin Extracted from Thai Native Silkworms (Bombyx mori). Pharmaceutical Biology, 48, 855-860. http://dx.doi.org/10.3109/13880200903300212

[8] Rhee, W.J., Park, J.H., Hahn, J.S. and Park, T.H. (2013) Anti-Apoptotic Mechanism of Silkworm Hemolymph in HeLa Cell Apoptosis. Process Biochemistry, 48, 1375-1380. http://dx.doi.org/10.1016/j.procbio.2013.06.018

[9] Mondal, M., Trivedy, K. and Kumar, S.N. (2007) The Silk Proteins, Sericin and Fibroin in Silkworm, Bombyx mori Linn.,-A Review. Caspian Journal of Evironmental Siences, 5, 63-76.

[10] Chon, J.W., Kweon, H., Jo, Y.Y., Park, M.K., Son, Y.H. and Lee, H.S. (2012) A Study on the Development of Functional Cosmetics Using Silk-Grand Power of Silkworm. Journal of the Society of Cosmetic Scientists of Korea, 38, 163-169.

[11] Haddad, A.L., Matos, L.F., Brunstein, F., Ferreira, L.M., Silva, A. and Costa, D. (2003) A Clinical, Prospective, Randomized, Double-Blind Trial Comparing Skin Whitening Complex with Hydroquinone vs. Placebo in the Treatment of Melasma. International Journal of Dermatology, 42, 153-156. http://dx.doi.org/10.1046/j.1365-4362.2003.01621.x

[12] Murata, K., Takahashi, K., Nakamura, H., Itoh, K. and Matsuda, H. (2014) Search for Skin-Whitening Agent from Prunus Plants and the Molecular Targets in Melanogenesis Pathway of Active Compounds. Natural Product Communications, 9, 185-188.

[13] Winder, A., Kobayashi, T., Tsukamoto, K., Urabe, K., Aroca, P., Kameyama, K. and Hearing, V. (1993) The Tyrosinase Gene Family-Interactions of Melanogenic Proteins to Regulate Melanogenesis. Cellular \& Molecular Biology Research, 40, 613-626.

[14] Jackson, I.J., Chambers, D., Tsukamoto, K., Copeland, N., Gilbert, D., Jenkins, N. and Hearing, V. (1992) A Second Tyrosinase-Related Protein, TRP-2, Maps to and Is Mutated at the Mouse Slaty Locus. The EMBO Journal, 11, 527535.

[15] Yen, F.L., Wang, M.C., Liang, C.J., Ko, H.H. and Lee, C.W. (2012) Melanogenesis Inhibitor(s) from Phyla Nodiflora Extract. Evidence-Based Complementary and Alternative Medicine, 2012, Article ID: 867494.

[16] Park, H.J., Kim, E.J., Koo, T.Y. and Park, T.H. (2003) Purification of Recombinant 30K Protein Produced in Escherichia coli and Its Anti-Apoptotic Effect in Mammalian and Insect Cell Systems. Enzyme and Microbial Technology, 33, 466-471. http://dx.doi.org/10.1016/S0141-0229(03)00149-2

[17] Izumi, S., Fujie, J., Yamada, S. and Tomino, S. (1981) Molecular Properties and Biosynthesis of Major Plasma Proteins in Bombyx mori. Biochimica et Biophysica Acta-Protein Structure, 670, 222-229. http://dx.doi.org/10.1016/0005-2795(81)90013-1

[18] Pietrzyk, A.J., Bujacz, A., Mueller-Dieckmann, J., Lochynska, M., Jaskolski, M. and Bujacz, G. (2013) Two Crystal Structures of Bombyx mori Lipoprotein 3-Structural Characterization of a New 30-kDa Lipoprotein Family Member. PLoS ONE, 8, Article ID: e61303. http://dx.doi.org/10.1371/journal.pone.0061303

[19] Kim, E.J. and Park, T.H. (2004) Increase of Host Cell Longevity by the Expression of 30K Protein Originating from Silkworm Hemolymph in an Insect Cell-Baculovirus System. Enzyme and Microbial Technology, 35, 581-586. http://dx.doi.org/10.1016/j.enzmictec.2004.08.024

[20] Rhee, W.J., Kim, E.J. and Park, T.H. (2002) Silkworm Hemolymph as a Potent Inhibitor of Apoptosis in Sf9 Cells. Biochemical and Biophysical Research Communications, 295, 779-783. http://dx.doi.org/10.1016/S0006-291X(02)00746-5

[21] Rhee, W.J., Lee, E.H., Park, J.H., Lee, J.E. and Park, T.H. (2007) Inhibition of HeLa Cell Apoptosis by Storage-Protein 2. Biotechnology Progress, 23, 1441-1446. http://dx.doi.org/10.1021/bp0702065

[22] Jung, J.H., Hwang, J.W., Kim, H., Cha, H.M., Kim, D.I. and Choi, Y.S. (2013) Whitening and Anti-Aging Activities of Soluble Silkworm Gland Hydrolysate. Korean Society for Biotechnology and Bioengineering Journal, 28, $196-201$. 
[23] Costin, G.E. and Hearing, V.J. (2007) Human Skin Pigmentation: Melanocytes Modulate Skin Color in Response to Stress. The Journal of the Federation of American Societies for Experimental Biology, 21, 976-994. http://dx.doi.org/10.1096/fj.06-6649rev

[24] Hwang, J.W., Lee, H.S., Kim, H., Kim, K.O. and Choi, Y.S. (2012) Manufacture and Characterization of Silkworm Gland Hydrolysate. Journal of Sericin and Entomology Science, 50, 76-81.

[25] Choi, M.H., Cha, H.M., Kim, S.M., Choi, Y.S. and Kim, D.I. (2013) Effects of Silkworm Gland Hydrolysate on Albumin-Erythropoietin Production in Transgenic Chinese Hamster Ovary Cells. Korean Society for Biotechnology and Bioengineering Journal, 28, 86-91.

[26] Cheon, Y., Hwang, J.W., Lee, H.S., Yun, S., Choi, Y.S. and Kang, S. (2013) Anti-Oxidant and Anti-Aging Activities of Sericinjam Gland Hydrolysate Extract in Human Dermal Fibroblasts. Journal of the Society of Cosmetic Scientists of Korea, 39, 9-17.

[27] Yu, W., Wang, M., Zhang, H., Quan, Y. and Zhang, Y. (2013) Expression and Functional Analysis of Storage Protein 2 in the Silkworm, Bombyx mori. International Journal of Genomics, 2013, Article ID: 145450.

[28] Chang, T.S. and Chen, C.T. (2012) Inhibitory Effect of Homochlorcyclizine on Melanogenesis in $\alpha$-Melanocyte Stimulating Hormone-Stimulated Mouse B16 Melanoma Cells. Archives of Pharmacal Research, 35, 119-127. http://dx.doi.org/10.1007/s12272-012-0113-z

[29] Lee, S.A., Son, Y.O., Kook, S.H., Choi, K.C. and Lee, J.C. (2011) Ascorbic Acid Increases the Activity and Synthesis of Tyrosinase in B16F10 Cells through Activation of p38 Mitogen-Activated Protein Kinase. Archives of Dermatological Research, 303, 669-678. http://dx.doi.org/10.1007/s00403-011-1158-4

[30] Różanowska, M., Sarna, T., Land, E.J. and Truscott, T.G. (1999) Free Radical Scavenging Properties of Melanin: Interaction of Eu- and Pheo-Melanin Models with Reducing and Oxidising Radicals. Free Radical Biology and Medicine, 26, 518-525. http://dx.doi.org/10.1016/S0891-5849(98)00234-2

[31] Nappi, A., Vass, E., Frey, F. and Carton, Y. (1995) Superoxide Anion Generation in Drosophila during Melanotic Encapsulation of Parasites. European Journal of Cell Niology, 68, 450-456.

[32] Momtaz, S., Mapunya, B., Houghton, P., Edgerly, C., Hussein, A., Naidoo, S. and Lall, N. (2008) Tyrosinase Inhibition by Extracts and Constituents of Sideroxylon inerme L. Stem Bark, Used in South Africa for Skin Lightening. Journal of Ethnopharmacology, 119, 507-512. http://dx.doi.org/10.1016/j.jep.2008.06.006

[33] Kumano, Y., Sakamoto, T., Egawa, M., Iwai, I., Tanaka, M. and Yamamoto, I. (1998) In Vitro and in Vivo Prolonged Biological Activities of Novel Citamin C Derivative, 2-O- $\alpha$-D-Glucopyranosyl-L-Ascorbic Acid (AA-2G), in Cosmetic Fields. Journal of Nutritional Science and Vitaminology, 44, 345-359. http://dx.doi.org/10.3177/jnsv.44.345

[34] Akihisa, T., Kawashima, K., Orido, M., Akazawa, H., Matsumoto, M., Yamamoto, A., Ogihara, E., Fukatsu, M., Tokuda, H. and Fuji, J. (2013) Antioxidative and Melanogenesis-Inhibitory Activities of Caffeoylquinic Acids and Other Compounds from Moxa. Chemistry \& Biodiversity, 10, 313-327. http://dx.doi.org/10.1002/cbdv.201200357

[35] Saino, N., Romano, M., Rubolini, D., Ambrosini, R., Caprioli, M., Milzani, A., Costanzo, A., Colombo, G., Canova, L. and Wakamatsu, K. (2013) Viability Is Associated with Melanin-Based Coloration in the Barn Swallow (Hirundo rustica). PLoS ONE, 8, Article ID: e60426. http://dx.doi.org/10.1371/journal.pone.0060426

[36] Kondo, T. and Hearing, V.J. (2011) Update on the Ascorbic Acid Increases the Activity and Synthesis of Tyrosinase in B16F10 Cells through Activation of p38 Mitogen-Activated Protein Kinase Regulation of Mammalian Melanocyte Function and Skin Pigmentation. Expert Review of Dermatology, 6, 97-108. http://dx.doi.org/10.1586/edm.10.70 
Scientific Research Publishing (SCIRP) is one of the largest Open Access journal publishers. It is currently publishing more than 200 open access, online, peer-reviewed journals covering a wide range of academic disciplines. SCIRP serves the worldwide academic communities and contributes to the progress and application of science with its publication.

Other selected journals from SCIRP are listed as below. Submit your manuscript to us via either submit@scirp.org or Online Submission Portal.
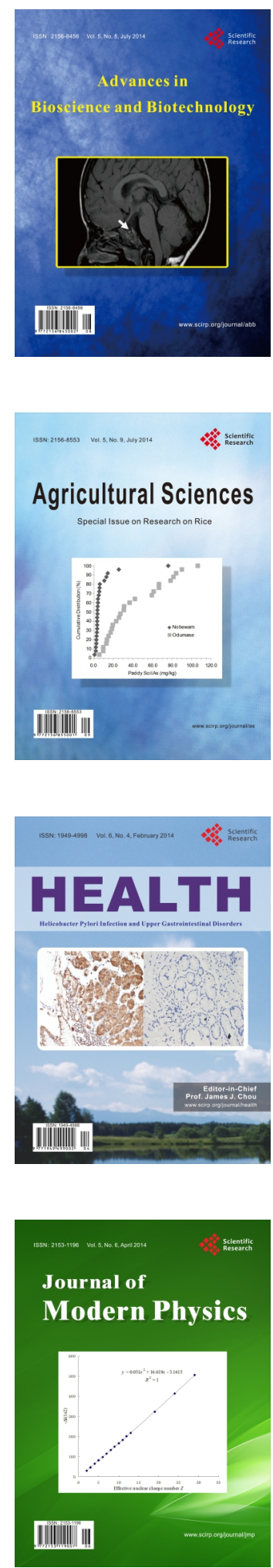
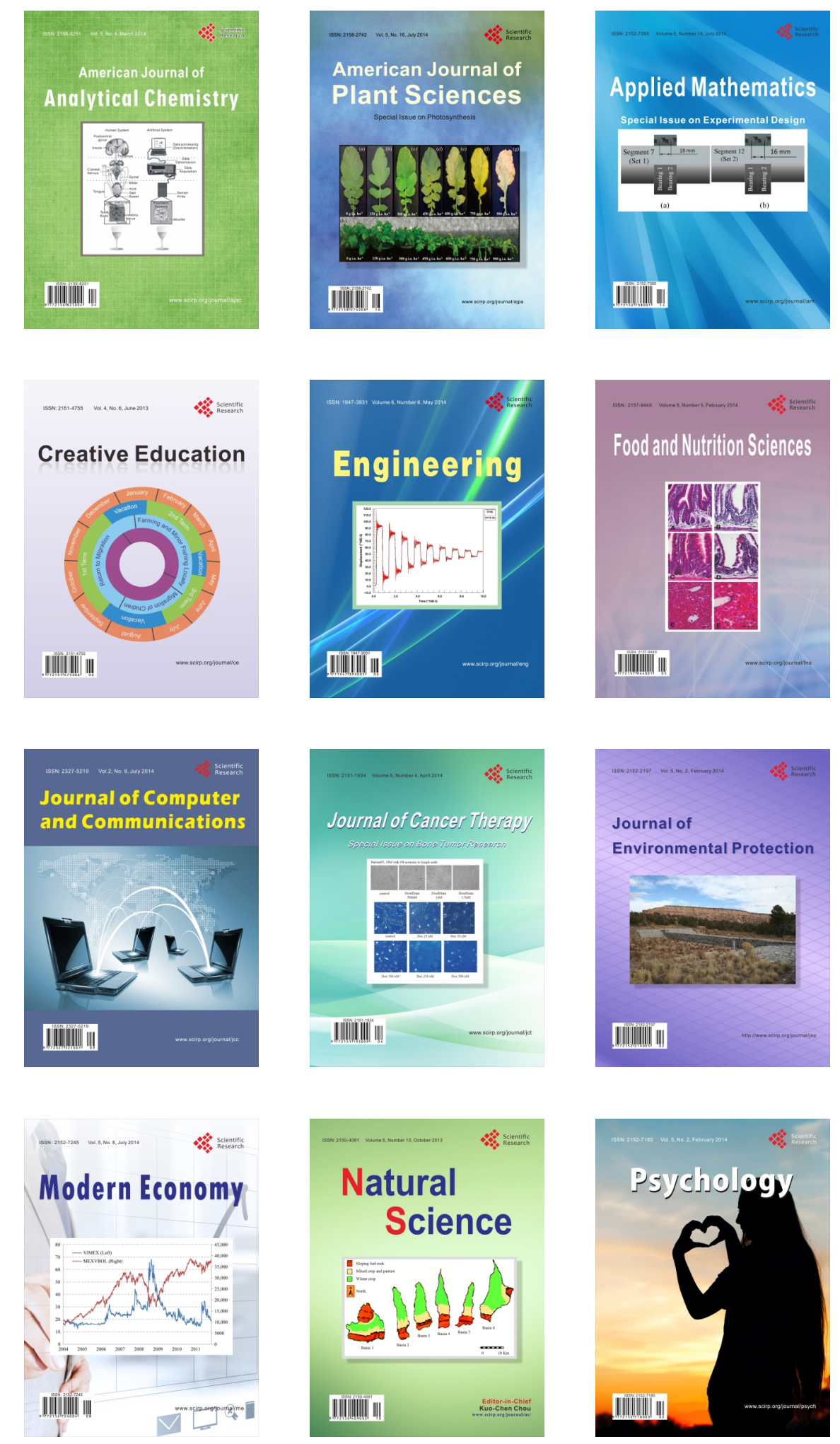